\title{
'New' Men and 'New' Women: Cultural Identity Work of Husbands and Wives Related to Housework and Childcare
}

\author{
Nasima M. H. Carrim ${ }^{1}$ \\ ${ }^{1}$ Department of Human Resource Management, University of Pretoria, Pretoria, South Africa \\ Correspondence: Nasima M. H. Carrim, Department of Human Resource Management, University of Pretoria, \\ Pretoria, Gauteng, South Africa. Tel: 27-420-2466. E-mail: nasima.carrim@up.ac.za
}

Received: August 30, 2017

Accepted: September 20, 2017

Online Published: October 28, 2017

doi:10.5539/ass.v13n11p1

URL: https://doi.org/10.5539/ass.v13n11p1

\begin{abstract}
Existing research indicates that the number of dual-career couples is increasing and that, by implication, domestic responsibility should be equally shared between husbands and wives. However, in many societies, women's paid employment has not resulted in men assuming responsibility for domestic duties and childcare. This article examines the extent to which husbands and wives engage in cultural identity work related to household chores and childcare. A qualitative interpretivist approach was followed and semi-structured interviews were conducted with 25 Indian couples occupying different positions across various management levels in diverse South African organisations. The results of the study indicate that these husbands and wives, who come from diverse socio-economic backgrounds, engage differently in cultural identity work. Additionally, today's younger wives are more assertive and expect their husbands to be involved to a greater extent in the home and with childcare, resulting in husbands engaging in more identity work. The Indian society in South Africa is undergoing tremendous changes regarding adherence to culture, resulting in varying levels of cultural identity work taking place within dual-earner relationships.
\end{abstract}

Keywords: dual-earner couples, cultural identity work, housework, childcare, South Africa

\section{Introduction}

An increase in the number of women entering the workforce, not only worldwide (Bianchi \& Milkie, 2010) but also in South Africa (Department of Labour, 2016), has resulted in the transformation of traditional gender roles in many homes, especially when wives occupy full-time jobs and men assume greater roles in the home (Ahmed \& Carrim, 2016). Men are no longer the sole breadwinners in their families: women also contribute to household expenses (Carrim, 2016). In the past, the myth surrounding the concept of a dual-career relationship was that work and family were separate spheres. A dual-career relationship is referred to as a 'work-family system' that embraces the work and family roles of both husband and wife. These days, both men and women in most Western societies and cultures take on roles inside and outside the home (Bianchi \& Milkie, 2010).

In traditional societies, and in the majority of cases, division of labour in the home is strict: men are breadwinners and women are housewives (Carrim, 2012). For example, within the Indian society (consisting of individuals who trace their origins back to the Indian subcontinent), gender role division is prescribed for both males and females. Indian cultural norms dictate that domestic chores and childcare are women's domains and economic responsibility the realm of men (Carrim, 2016). Hence, within dual-career relationships the division of labour becomes a challenge especially when wives advance in their careers and may have to work late in the evenings and travel out of town on business. Husbands therefore start assuming some responsibility in the home and for childcare (Ahmed \& Carrim, 2016). This entry into the woman's domain becomes a challenge to the cultural identities of Indian husbands and wives and they ask themselves the question: who am I as an Indian male or female? As a result, they start engaging in identity work, a concept that is defined by Sveningsson and Alvesson (2003, p. 1165) as the way "individuals form, repair, maintain, strengthen or revise constructions that are productive of a sense of coherence and distinctiveness".

Most of the research conducted on housework and childcare has focused on wives' perspectives (Gupta, 2007; Zimmerman, 2003) and a limited number of studies have been done taking both husbands' and wives' perspectives into account (Ahmed, \& Carrim, 2016; Craig, 2007; Quek, Knudson-Martin, Orpen, \& Victor, 2011). Moreover, research on the responsibility for household chores and childcare among dual-earner couples 
has focused on Western perspectives (Cooke, 2007), whereas only some studies have focused on an Eastern perspective (Luke, Xu, \& Thampi, 2014; Narayan, \& Bhardwaj, 2005). Luke et al. (2014), who conducted a study on Indian women breadwinners working on tea plantations, found that when husbands earned less than wives, men participated to a lesser extent in domestic chores. The study of Narayan and Bhardwaj (2005), which was about dual-career couples in India, indicated that husbands did not get involved in household chores. These husbands indicated that their main responsibility was to be breadwinners and that the domestic domain remained their wives' responsibility. It has been established that the concept of household labour is embedded in complex and shifting patterns of social relations that relate to gender, family interactions, household structure and formal and informal market economies (Coltrane, 2000). Research has shown that men have been slow to adopt the idea of performing household chores, a phenomenon referred to in the literature as 'stalled revolution', and that this has made it more difficult for women to progress in the workplace (Thébaud, 2010, p. 332). Thébaud's research focused mainly on dual-earner couples from traditional societies and lower socio-economic classes, and little research has been done on how dual-earner couples who occupy managerial posts engage in cultural identity work related to housework and childcare. Additionally, sparse research exists in contexts where the socio-political-economic environment plays a role in the cultural shifts that occur in respect of adherence to cultural norms. Indications are that most research has not taken account of the question whether husbands and wives from a particular cultural group in a country engage in the same amount of identity work related to engaging with and disengaging from domestic chores and childcare respectively in their homes (Carrim, 2012).

In order to fill the gap in the existing literature as identified above, the aim of the current study is to focus on the extent to which Indian husbands and wives in dual-earning relationships in a South African context undertake cultural identity work regarding housework and childcare. The focus is on household chores and childcare, identity work and the South African context. The method used to explore this topic is explained and the results are presented and discussed.

The next section focuses on the aspects of household chores and childcare, cultural identity, identity work and the South African context.

\section{Theoretical Framework}

\subsection{Household Chores and Childcare}

In recent years, men's and women's distribution of time relating to paid and unpaid work has become similar in Western countries such as Canada, the United States, Australia and Europe (Sullivan, 2011). The difference in the time that men and women spend on unpaid work, such as household chores, cooking and childcare, has narrowed tremendously due to egalitarian gender views and an increase in women's marital power (Luke et al., 2014; Sullivan, 2011; Zimmerman, 2003). Husbands' greater involvement in housework could be attributed to wives having less time for these activities (Bianchi, Robinson, \& Milkie, 2006). Coltrane (2000) points out that although the majority of men and women agree that household chores and childcare should be shared, very few men assume equal responsibility for household labour, and most wives still carry the greatest responsibility (Craig 2007; Currie \& Eveline, 2011). In contrast, Zimmerman (2003) found in her study of 47 dual-career couples in the United States that both spouses shared housework equally. Coltrane (2000) posits that most men feel it is fair that women have to take more responsibility in the home and have extra housework as most men work longer hours than their wives. Men's involvement in housework is regarded as being optional and is seen as 'assisting' wives. However, within traditional cultures women assume greater responsibility for homework and childcare. For example, a study conducted by Das (2006) indicated that Asian Indian immigrant women in San Francisco requested assistance from husbands with household chores and childcare, but in most cases the men only took the children to school and put them to bed at night. She also found that Indian men who were employed for fewer hours, had more education and endorsed gender equity tended to do more housework.

Scholars have found that an individual's income brings bargaining power into play in a relationship, which implies that the more an individual earns the more bargaining power the person has to do less housework (Thébaud, 2010). However, there are limits to using income as an excuse not to do housework. Bittman, England, Sayer, Folbre, and Matheson, (2003) posit that the belief that men should do less housework and women more is a traditional gender belief that has little to do with what they earn. Even when women earn more and are able to decrease their household chores, they do not manage to get their husbands to perform more household duties. Men who earn about the same income as their spouses have been found to do more housework than men whose wives are at home. Furthermore, when the wives are the breadwinners, their husbands do not necessarily do more housework. In some cases, men who are dependent on their wives do even less housework than their wives (Thébaud, 2010). Furthermore, men who do housework do not do much to achieve parity or even to reverse 
traditional gender roles in the home (Thébaud, 2010). Das (2006) has found that women who have higher earnings enjoy egalitarian relationships in the home and have more power too. On the other hand, a study by Gupta (2007) indicates that the amount of housework women do is not affected by how much they or their husbands earn.

From the mid-1980s, men started spending more time with their children (Bianchi \& Milkie, 2010). How couples share parenting depends on whether they accept cultural prescripts regarding parenting and the role of mothers (Quek et al., 2011). Couples who collaborate believe that parenting should be shared (Matta \& Knudson-Martin, 2006). Although men seem to spend more time with children nowadays, the time mothers spend with children remains high (Bianchi et al., 2006; Matta \& Knudson-Martin, 2006). Research has indicated that women have less demanding jobs than men, which gives them more time to spend on childcare. The reason for this is that women's advancement to more demanding jobs (that require more time) is hampered by motherhood, which has a negative impact on the upward career mobility of many women (Correll, Benard, \& Paik, 2007). Bittman, Craig, and Folbre (2004) have found that fathers in the United States of America become more involved in childcare when they make use of non-parental child carers. Craig (2007) points out that whether wives work or not makes no difference to the time husbands spend with children. Quek et al. (2011) postulate that couples who share parenting tend to negotiate family responsibilities, and hence they are able to handle conflict better. The authors also point out that men's gender expectations and perceptions of work roles determine the extent to which domestic labour and parenting are shared.

This section focused on the division of labour in dual-earner homes, and the next section deals with cultural identity and the theoretical underpinning of identity work and how these aspects relate to husbands' domestic roles.

\subsection{Cultural Identity and Identity Work}

Hall (1990) contends that there are two ways of defining cultural identity. First, cultural identity is seen as depicting a shared culture that is rooted in a shared history and ancestry that one has in common with other people. Hence, one's cultural identity is a manifestation of the shared historical experiences and cultural codes that provide one with an unchanging, stable and continuous frame of reference beneath the shifting divisions of one's actual history. Second, cultural identity is comprised of many points of similarity but also of difference, reflecting what we have become due to the intervention of history. Thus, cultural identity belongs to the past as well as to the future. Cultural identities have a history but they are also constantly transformed and are therefore fluid (Hall, 1990).

An individual's community, family, religious institutions and peers play a part in the development of one's cultural identity (Erikson, 1968). Hence, an individual's cultural identity develops based on the norms, attitudes, beliefs and values of one's cultural group, and which one accepts (Campbell, 2000). However, this socially constructed definition of cultural identity fails to include the possibility that individuals may identify with their cultures to varying degrees, especially when these are transmitted across generations or when socio-economic and political contexts change (Grossman \& Charmaraman, 2009) because these two factors may influence social arrangements within homes. In addition, according to the social identity theory, individuals identify with different roles; hence, individuals who identify with a group will adopt the behaviors and attitudes of that group (Tajfel \& Turner, 1985). As indicated by Ashforth and Mael (1989), individuals who identify with a group will, in the first place, select activities compatible with the salient social identity, and secondly, they will remain loyal to the group in spite of negative attributes. Thirdly, individuals conform to group norms and attributes that reflect their own archetypal characteristics, in that way reinforcing the group's values, prestige and practices. Thus, Indian men will assume traditional cultural roles as long as others enforce these in their surroundings; the reason being that within Indian society, socio-cultural influence plays an important role and social acceptance is valued above individual decision-taking as people want to feel secure and accepted within the society (Banerjee, 2008). Hence, the question of 'who are we?' takes precedence over the question 'who am I?' However, when traditional roles, such as gender roles, start to weaken or change due to Western influences (for instance, when men assume more domestic responsibilities), the result is that men have to work and rework their cultural identities to accommodate new roles and identities, resulting in cultural identity work. Thus, cultural identity work refers to the extent to which men and women from traditional cultures work and rework their identities to diminish the anxiety they feel in moving away from, for example, prescribed social gender norms (Carrim, 2012). Studies done in India reveal that the number of dual-career households has increased but that men in these households still cling to their traditional cultural identities and values. For example, Salway, Jesmin, and Rahman (2005) conducted a study on dual-career earners in Bangladesh and discovered that husbands felt anxious if their wives worked outside the home as it went against their cultural identities of being the sole breadwinners. Husbands, 
therefore, achieved cultural identity congruence by being the sole decision-maker in the home and not providing wives with instrumental domestic support.

In patriarchal and hierarchical societies, such as the Indian community, the cultural identities of men and women are rigid (Coltrane, 2000). Men's cultural identities are based on their role as the breadwinner, their involvement with activities outside the home and their lack of involvement in household duties. Within such societies, men have higher status and more privileges compared to women, and men are less involved than women in household chores and childcare (Saraff \& Srivastava, 2010). Since gender roles are rigid in these societies, men do not give wives social support (Kulik \& Rayyan, 2006), as a result of which they engage in minimal cultural identity work. On the other hand, in egalitarian societies men have less rigid cultural identities, men and women are treated similarly and they are given equal rewards, status and opportunities (Kulik \& Rayyan, 2006), as a result of which it is assumed that more cultural identity work may be required.

Within the Indian culture, gender norms tend to be more traditional and men assume more power. In this culture, traditional gender roles do not allow working women to have any bargaining power regardless of their earning power. Hence, women cannot negotiate certain household chores with husbands (Schneider, 2011) as men are the decision-makers and women are responsible for childcare and domestic labour (Saraff \& Srivastava, 2010). Therefore, traditionally Indian men engage in minimal cultural identity work as couples prescribe and adhere to roles. Rajadhyaksha and Velgach (2009) found in their study of 160 dual-earner couples in India that women wanted their husbands to assist them in the home. However, traditional cultural roles in India are slow to change as husbands hold on to traditional cultural identities.

Kulik and Rayyan (2006) point out that, in addition to the dictates of culture, the values and norms of the macro environment influence the attitudes of an individual toward gender roles and the division of domestic labour and childcare. Research indicates that men's share of domestic labour and participation varies across countries (Kan, Sullivan, \& Gershuny, 2011; Ruppanner, 2010). These differences are attributed to social policies related to women's labour force participation and childcare (Cooke, 2007). Men who live in countries that have liberal welfare systems assume a bigger share of the housework compared to men who live in countries that have conservative policies. Conservative policies advocate traditional gender roles and follow the model of the male being the breadwinner and the female being the caregiver (Cooke, 2007; Kan et al., 2011; Ruppanner, 2010). However, a drawback of studies such as these is that they cannot account for all variables, such as the cultures of individuals.

Next, the attention turns to the South African context.

\subsection{GenderRoles in the South African Indian Community}

Historically, during the colonialist and apartheid eras, men held power in South African society albeit to varying degrees. Whites had the most power and Africans the least, whereas Indians had somewhat more power than the latter group (Carrim \& Nkomo, 2016). South Africa was based on a patriarchal system where men dominated in the workplace and the home. In Indian homes, men were the breadwinners as women were not allowed to enter the workplace due to a lack of job opportunities during apartheid and as they were expected to uphold the respectability of their families (Vangarajaloo, 2011). Also, residential segregation was legislated with the introduction of the Group Areas Act of 1950 that stipulated that Indians should reside in racially demarcated areas, leading to their establishing relationships mainly with members of their own racial group (Carrim, 2012). This resulted in Indians strictly following traditional gender roles although they had been in South Africa for more than a century, and this filtered through to sons and daughters who were raised and socialised to regard appropriate gender roles as vitally important to upholding cultural and religious values and beliefs (Vangarajaloo, 2011).

The reason for Indians holding on to their customs was that they were forced to live in segregated townships by the apartheid government. This monocultural environment reinforced their common heritage, values and norms (Ahmed, \& Carrim, 2016). Individuals and families had to subscribe to norms dictated by the community because rejecting these would have led to their being ostracised. Also, the patriarchal messages handed down from parents and extended family played a major role in the cultural identity work engaged in by the Indian men who participated in the current study. Subscribing to cultural values and norms allowed Indians in South Africa to have a positive sense of self in an otherwise negative macro environment. This resulted in Indians forming a collective identity according to which men were placed in leadership positions in their homes and communities (Carrim, 2012).

Although the 1994 elections ushered in a democratic era that allowed Indian women to enter the workplace, which resulted in an increase in dual-career couples, South African society still remains patriarchal 
(Vangarajaloo, 2011). Patriarchy is also practised in Indian homes where parents maintain Indian cultural norms and values related to gender roles (Carrim, 2016). However, the study by Carrim (2012) indicates that some Indian women managers who live in nuclear family units have managed to negotiate egalitarian relationships with husbands as far as household chores and childcare are concerned, but that others have not been able to do so. Nevertheless, Carrim's study does not focus on differences in the amount of household chores and childcare that husbands and wives undertake when wives occupy positions at managerial levels.

Based on the findings of previous studies, and taking the South African context into account, the following research questions emerged:

- To what extent do Indian husbands and wives adhere to prescribed cultural gender division of labour in their homes?

- Do Indian husbands and wives share household chores and childcare equally?

- Do wives who have progressed to senior and top management positions engage in more household chores and childcare compared to husbands whose wives have remained at lower management levels?

- Does the socio-economic background of husbands and wives have an impact on engagement in household chores and childcare?

\section{Method}

To comprehend the division of household labour and childcare between husbands and wives in dual-career couples' households, a qualitative, interpretivist approach was used. This approach was adopted as there is a need to understand the extent to which Indian dual-career couples engage in identity work related to their cultural identities in a democratic South Africa that is still steeped in patriarchal domestic division of labour (Bryman \& Bell, 2007). Semi-structured, life-story interviews were conducted to gain a perspective on the cultural identity work dual-career couples engaged in (Guba \& Lincoln, 1989). A life-story approach was used because prior studies on the cultural identity of Indians in Western countries tended to concentrate on Indians' current situation and not take historical context into account.

\subsection{Participants' Characteristics}

The biographical data indicated that nine male participants had obtained undergraduate degrees and 16 had obtained postgraduate degrees. The ages of the male participants ranged from 31 to 62 years. Participants occupied middle, senior and top management posts, which included positions as legal, financial, human resource, IT, strategic compliance and administrative managers and chief financial officers. Also included were a principal financial advisor and a manager each in engineering, risk compliance, procurement, communications and marketing. Seven male participants were in top management, 11 in senior management and seven in middle management. Of the female participants, 21 had obtained postgraduate degrees and four had completed undergraduate degrees. Their ages ranged from 30 to 60 years. The female participants occupied middle, senior and top management posts, which included human resource executive directors, legal executive directors, chief financial officers, marketing managers, project managers and financial managers. Four women were in top management, 12 in senior management and nine in middle management. To maintain confidentiality all participants were given pseudonyms.

\subsection{Sampling Procedures}

Purposive and snowball sampling were used (Babbie, 2008). The sample consisted of dual-earner couples who worked in the private and public sectors in South Africa. Initially, participants were contacted through LinkedIn, and they recommended colleagues and friends as possible participants. The purpose of the study was outlined to the participants, their informed consent was obtained and meetings were set up at participants' homes and workplaces.

\subsection{Measures}

Semi-structured interviews, each lasting between 60 and 90 minutes, were conducted and the aim was to compare participants' responses. Follow-up interviews were conducted for clarification and further probing. Data saturation was reached after having interviewed 22 dual-earner couples. A further three dual-earner couples from each management level were interviewed to ensure no new data emerged, and this aim was achieved. The author transcribed the data after each interview, read and reread the data several times to make meaning of the information the participants provided, and used open coding to assign codes to the data. Thereafter, themes were extracted using thematic analysis, and the data were constantly compared to allow themes to emerge in an inductive manner (Babbie, 2008). Through the use of axial coding, a relationship between the various open codes 
was revealed (Bryman \& Bell, 2007). The core code was identified, transcripts were reread and data were selectively coded in line with the core code (Babbie, 2008). To enhance the credibility of the study, transcripts of the interviews were handed to a trained observer who is an expert in qualitative research methodology and also familiar with research on dual-earner studies to code the themes independently. In a face-to-face session between the author and the observer it was established that the themes they had extracted were similar, which further enhanced the credibility of the study. On being provided with a copy of the final themes the participants confirmed that their narratives had been captured accurately.

Three overarching themes were extracted from the interviews: non-engagement of spouses, engagement of both spouses, and wives' assumption of full responsibility.

\section{Results}

\subsection{Non-engagement of Spouses}

One of the findings of the study was that the husbands and wives who occupied top management positions had not engaged in household chores and childcare from the time they got married. All four of the couples married straight after completing their undergraduate university degrees and outsourced cooking and childcare to grandparents and family friends. Malaika indicated that she had engaged to a minimal extent in household chores and childcare in the course of her marriage:

My husband always wanted me to progress in my career and he supported me. For the past 31 years of marriage I have done minimal housework. Even when our house help used to be sick, I used to get casual help. Women are always looking for casual work in the house and there was always an oversupply of house help. I also got the assistance of an au pair to take care of my babies. I would leave my babies by my mother and the au pair would assist her in taking care of them. My mother would also cook for us. I have forgotten how to cook a good Indian meal because I have not cooked in years.

Adnaan, Malaika's husband, commented as follows:

For us our careers came first. There was no time for housework and childcare. Our children have turned out fine as they are independent and both at university. For the past few years, we have hired a cook as my mom-in-law is old and we don't want to burden her with cooking.

All the couples in top management posts who were asked about the norms regarding household chores in their natal homes and extended families indicated that there had been a strong division of labour when they were growing up, a trend that had not changed since. Kamla, like the other women in top management posts, indicated the difficulty she had experienced adhering to cultural gender roles when she was growing up and that she negotiated these roles with her husband:

I was not one for housework and cooking. My mother had a difficult time convincing me to cook and clean. Whenever I had to assist her in the home, I would go to my room and start with my schoolwork. My father used to tell her to leave me to focus on my studies. I found it difficult to engage in conversations with my friends when I was at university. They all married immediately after completing school and spoke about raising children and cooking. I couldn't fit into the cultural mould of being a 'typical' housewife and mother. I found that aspect of the Indian culture difficult to conform to and my mother would always hear remarks from aunts about how I will suffer in my marriage if I did not know how to cook and take care of a home. Before I married, I discussed this issue with my husband that I did not know how to cook and was not interested in household chores, as I wanted to advance in my career. My husband also wanted me to succeed so he agreed to my outsourcing all household chores and childcare.

In the late 1980s, when the majority of the participants entered university, the Indian community was undergoing changes as more young women were encouraged to pursue tertiary education and careers (Carrim, 2012). This was a rare phenomenon among South African Indians as only a handful of women from the participants' parents' generation had pursued tertiary education and careers. Also, an increasing number of Indian males entered universities as the cracks in the apartheid system became visible during the late 1980s and tertiary institutions were accepting larger numbers of Indian students (Carrim, 2012). The majority of the male participants mentioned that living away from home and having to clean and cook gave them a more emancipated outlook on life. Also, the majority of the couples indicated that a few of their aunts were professionals at a time when a handful of Indian women pursued careers in South Africa. This resulted in their husbands adopting a liberal outlook on women's engagement in household chores and childcare. Udit, Kamla's husband, indicated that his aunt was a doctor and he used to visit her regularly. He noticed that she did not engage in household chores and childcare, which had a great impact on how he viewed women's roles in the home: 
Although I was raised in a home where women had to clean and cook, my views on women's duties were influenced by my experiences. At university I lived in my own apartment and I had to clean and cook so I was aware of the difficulties balancing home and a career. Another influence was my aunt who was a doctor and I never saw her cooking, cleaning the house or even taking care of my cousins. She outsourced all these chores and focused on her career. It was at first difficult for me to make the adjustment of allowing my wife to be like my aunt as the community we were raised in was conservative and such behaviour was frowned upon. But things are changing in the Indian community and people are becoming somewhat more open-minded.

Wives in top management posts indicated that after their marriage their mothers-in-law would frown upon their not taking care of their homes and families. Bahiyya commented on her mother-in-law's remarks about her being a bad mother and housewife:

My mother-in-law always tells my husband that I'm a bad wife and mother as I do not cook, clean and take care of my children. I sometimes feel guilty for not being a good wife and mother and not living up to cultural expectations. It is hard to balance one's culture with what you want as the two clash and create lots of conflict within oneself. Sometimes I feel my mother-in-law is right, and I should give up my career. It's difficult to do so as I enjoy my career and I would never fit the role of being a housewife.

Numair, Bahiyya's husband, supported his wife:

My mom comes from the old school. Indian culture within South Africa is evolving all the time. We cannot stifle our wives by forcing them to do housework and care for children when we can outsource these activities. We need to understand that we need to enable highly intelligent women the freedom to explore their potential and to move up the corporate ladder. Yes, it's not easy in our society to allow wives not to engage in household chores and childcare as husbands also have to hear remarks from older family members. But times have changed and we need to keep up with changes in society otherwise we will stagnate.

\subsection{Engagement of Both Spouses}

Some couples in senior management were from middle-class families who upheld the norm that wives had to engage in household chores and cooking. However, the wives indicated that their husbands assisted them to some extent with household chores and childcare when assistance was needed, for instance when they had to study or attend meetings late in the evening. Nevertheless, the wives remained responsible for cooking and childcare. In the majority of the cases, wives would prepare food for the week on Sundays and warm a different dish every day. Some wives would wake up early in the morning and prepare a simple meal. However, childcare and household chores were assigned to au pairs and house helps respectively. Both spouses would be involved in assisting children with schoolwork in the evenings. Farida indicated that her husband had supported her tremendously by cooking and taking care of the children so that she could study for her postgraduate degree:

When I was completing my master's degree my husband would help me to prepare meals for the week over weekends and he would also take care of the children's homework. It was a bit strange to me at first as I was raised in a home where women did all the household chores and cooking. It took me a few years to get used to the idea that my husband plays a role in childcare and cooking. In a way I was glad he was around to assist. Since our families will not understand our household arrangements we don't broadcast it as our community is very close-minded about women's roles in the home.

Husbands at senior management level also indicated that in some cases they had no choice but to assist their wives in preparing meals and taking care of the children as they did not live near their parents and assistance from extended family members was not readily available. However, they did not do household chores as household helpers were abundantly available and easy to obtain. Farhaan, Farida's husband who is an IT support manager, found it very difficult to engage in household chores:

I assist my wife but to a minimal extent as I am still of the old school. I assist her with cooking when she is unable to do so as I prefer my traditional home-cooked food. I also assist the kids with their homework and that takes a bit of the burden off my wife. But I abstain from cleaning the house as I feel that's not my job.

Some couples who occupy senior management posts were raised in families of lower socio-economic status, and their stories differed somewhat from the stories of senior managers raised in middle-class families. The former indicated that both sons and daughters had to do household chores and take care of younger siblings. They did not have the luxury of thinking about cultural norms; their focus was on economic survival. Therefore, after marriage both husbands and wives were equally involved in household chores and childcare and hence they engaged in minimal cultural identity work. Vandana, like the other wives from a lower socio-economic background, indicated that her husband had assisted with housework and childcare from the start: 
We both come from poor families and are used to housework. There was no division of labour for men and women in our homes as we had to pull our resources just to survive so our parents could earn a living to sustain the family. My husband doesn't feel shy to assist me in the home.

Bhavik elaborated as follows:

My mom used to be very tired when she used to come home from the factory. As I was the eldest child in the family, I used to cook, clean the house and take care of my younger siblings. I used to bathe them and help them with their homework. In our neighbourhood all boys used to help with household chores so when I got married I assisted my wife. For us, cultural norms were secondary. We were raised to share household burdens equally with women.

Participants who were younger than 35, at middle management level and raised in middle-class families indicated that it was very difficult for them initially to adjust to assisting their wives in the home because in their parental homes the women had been responsible for housework and childcare. They admitted that younger women of the day were assertive and wanted to be in egalitarian relationships. Although the younger male participants were uncomfortable at first in getting involved with housework and childcare, they acceded eventually as the modern trend in their communities was for younger professional men to assist their wives in the home. Salman, a maintenance manager, indicated his outrage at having to get involved in household chores:

I was very unhappy with my wife asking me to assist in housework and childcare. This was definitely not the trend in our home and community. I spoke to a few friends and they told me that their wives are also insisting that they assist in the home. They convinced me to assist my wife in the home as professional women have become more demanding and they asked me if I was willing to go through several divorces just because wives need assistance in the house. I took their advice and got involved in housework and childcare. A few months ago, we visited my parents and our baby messed her diaper. My wife placed the baby in my lap and said it was my turn to change the diaper. My father raised his eyebrows and told me that in his day no woman would instruct him to change a diaper and that I should start wearing the pants in my home and not take instructions from my wife.

Fatima, Salman's wife, indicated, as did the other women in the study, that Indian women were no longer as passive as their predecessors and that they expected their husbands to be more involved with household chores and childcare. The participants admitted that men were aware that sometimes women had a greater chance than men to advance in their careers due to legislation favouring females. Hence, wives needed the support of their husbands to occupy high management positions. Dipti, like the other women who had higher-level management posts than their husbands, indicated that due to her career level she spent more time at the office than her husband. When she was not at home, her husband took over household responsibilities. Dipti commented:

My husband encouraged me to apply for a senior management post. I got the position but I also had much more responsibilities. He had to face reality and put in more effort in the home although he was not very happy about doing so at first. He has accepted to get more involved in household chores and childcare as we need the extra money to support his parents and my parents. He is an only child and I am one of two sisters. My sister is married and not working, so she cannot assist our parents financially.

Wives who were employed at higher management levels and earned more than their husbands indicated that their husbands shared household chores and childcare equally with them. Muktaar confirmed the comment of his wife Lamees that he was involved in all aspects of household chores and childcare:

My husband and I take turns in cooking, taking care of the children and housework. When I'm busy he takes over all household duties. When he is busy, I do likewise. We have an equal partnership.

\subsection{Wives'Assumption of Full Responsibility}

Some of the women participants found it difficult to advance in their careers as their husbands did not share responsibility for household chores and childcare. In the majority of cases, women participants stagnated at middle management levels, while husbands advanced to senior and top management posts. Wives indicated that they had been raised in homes where women would take full responsibility for housework and childcare and not ask husbands, brothers and sons to assist. They also placed husbands' careers before their own. For these women, moving away from cultural values and norms was difficult and they still adhered strongly to gender division of labour. Husbands also indicated that they believed that wives were responsible for household chores and childcare. Nayna, like the other women, admitted that she gave precedence to her husband's career and that she was responsible for household chores and childcare in the home:

I believe that a woman's role is to advance her husband's career. I therefore take care of the children, see to their 
homework, their extramural activities, I cook every day and see to the dishes in the evenings. When the house help is not around, I clean the house with the help of my children.

Nayna's husband Jayesh remarked:

I grew up in a home and community where a woman is responsible for the home and her career is secondary. My mom was a seamstress, but she made sure that she first saw to the house and our needs and then only did she see to her clients. In our community, respectable women are supposed to see to their homes and children and thereafter focus on their careers. Otherwise, people will make a laughing stock out of you.

Participants who subscribed strongly to gender division of labour in the home indicated that a male who engaged in household chores and childcare became the butt of other Indian men's jokes in the community. Raeesa echoed the views of some of the other participants who adhered to the gender division of labour:

I remember one day my brother's friends came to visit him. He was vacuuming the carpets. When they caught him vacuuming the carpets they teased him so much that to this day he does not take part in any household chores nor childcare.

\section{Discussion}

This study explored the cultural identity work related to housework and childcare of Indian husbands and wives in dual-career relationships. Overall, the findings were multifaceted across different management and socio-economic levels. Husbands and wives who aspired to be in top management negated cultural norms and engaged in minimal identity work: they focused more on career advancement than on the division of labour in the home. At this level the focus was more on individual attainment and less on adhering to cultural values or being concerned about the negative remarks of family members. These findings indicate that in some South African Indian dual-earner households there is a definite move away from cultural gender role prescripts in the home even though parents and extended family members may frown upon it. This finding corroborates the finding of Rajadhyaksha and Velgach (2009) that egalitarian notions are transforming the gender roles of women in households worldwide, albeit at a slow pace. Additionally, wives in egalitarian households are not inclined toward housework and childcare and prefer to move up the corporate ladder, a finding that contradicts the notion that Indian women subscribe to the traditional social norm of placing family needs above their own (Carrim, 2012). The finding of the current study was that minimal cultural identity work occurred in the case of spouses who had been raised in lower socio-economic households where the focus had been on survival instead of on adherence to cultural prescripts. Spouses from lower socio-economic groups were accustomed to equal gender roles in the home and did not adhere rigidly to traditional customs. In contrast, Luke et al. (2014) found in their study that husbands from lower socio-economic groups engaged to a lesser extent in domestic chores and childcare.

Spouses in the current study at senior and middle management levels indicated that they undertook a lot of cultural identity work regarding the division of labour. Husbands and wives were raised in families where strong divisions of labour existed. Therefore, husbands at first found it difficult to engage in housework and childcare, but their wives' need for spousal support due to workplace demands resulted in husbands engaging selectively in housework and childcare. Also, younger wives' increasing assertiveness in marriages resulted in husbands playing a greater role in household chores and childcare. Some wives were uncomfortable with and experienced some conflict about husbands' changed role in the home as they felt they had negated the cultural norm of being 'good' mothers and wives. However, younger wives did not experience any discomfort about husbands assisting with housework and childcare (Valk \& Srinivasan, 2011), which indicated that society was changing and there was a shift away from upholding traditional norms in the home. However, the cultural identity negotiation of some male participants did not take place immediately. At first, they 'secretly' practised individualistic 'domestic' behaviours and only after observing others publicly displaying similar behaviours did they follow suit. This behaviour confirms the assertion of Banerjee (2008) that individuals in the Indian culture follow others, in particular in regard to behaviours that are not sanctioned. In other cases, husbands assisted wives within the home only. Ezzedeen and Ritchie (2008) point out that traditional roles in dual-earner households are slowly transforming as husbands are engaging in roles previously reserved for women only.

Another finding of the current study was that in some dual-earner relationships, traditional Indian values were firmly entrenched in the psyche of some participants. As these participants upheld their traditional values, they engaged in minimal cultural identity work. This finding is in line with the finding of research conducted in India that women's entry into the corporate environment did not increase husbands' involvement in household chores and childcare (Carrim, 2016). Hence, husbands have more power in the home and household arrangements are not negotiated as wives also uphold patriarchal values by not demanding their husbands' assistance with 
domestic chores. This point was illustrated by Nayna when she said: "I believe that a woman's role is to advance her husband's career. I therefore take care of the children, see to their homework, their extramural activities, I cook every day and see to the dishes in the evenings. When the house help is not around, I clean the house with the help of my children."

Over time, some participants have negotiated and renegotiated their cultural identities whereas others have not. Husbands' engagement in cultural identity work is attributed to their having professional wives who reject the notion that women are responsible for domestic work. Bacon (1997) refers to professional women in Indian immigrant families in the United States and United Kingdom who are redefining gender roles. Women are redefining what it is to be Indian based on their lived experiences and they are influencing gender roles in the home by expecting their husbands to take equal responsibility for domestic chores and childcare. The redefinition of gender roles within the home is also taking place in some dual-earner families in South Africa.

To conclude, the point of departure in this study was to focus on the perspectives of Indian spouses so as to reach an understanding of the extent to which South African Indian dual-earner couples engage in cultural identity work relating to housework and childcare. As revealed in this study, some couples are in some respects more culture-bound than others. Some couples find it more difficult to deviate from prescribed roles: they are 'caught' in their old, traditional ways and find it difficult to work and rework their cultural identities. Some husbands who have weaker ties to the Indian culture are more flexible and better able to negotiate their cultural identities relating to engaging in housework and childcare in the home. Although attitudes are changing, heterosexual relationships are still dominated by gender-based power disparities (Zimmerman, 2003). One of the limitations of the study is that it did not focus on dual-career couples who occupied positions at lower levels. Future research could address this. Another limitation is that the study only focused on Indians born and raised in South Africa. Future research could focus on the experiences of migrant dual-career earners. A third limitation is that the study focused on Indian dual-earners. Future research could focus on dual-career earners from other traditional cultural groups and their involvement in housework and childcare. This study could serve as a basis for understanding the cultural identity work engaged in by the last three groups.

\section{References}

Ahmed, S. F., \& Carrim, N. M. H. (2016). Indian husbands' support of their wives' upward mobility in corporate South Africa: Wives' perspectives. South African Journal of Industrial Psychology, 42(1), 1-13. http://dx.doi.org/10.4102/sajip.v42i1.1354

Ashforth, B. E., \& Mael, F. (1989). Social identity theory and the organization. Academy of Management Review, 14(1), 20-39. https://doi.org/10.5465/AMR.1989.4278999

Babbie, E. (2008). The basics of social research (4th ed.). Belmont, CA: Thomson Wadsworth.

Bacon, J. (1997). Life lines: Community, family and assimilation among Asian Indian immigrants. New York, NY: Oxford University Press.

Banerjee, S. (2008). Dimensions of Indian culture, core cultural values and marketing implications: An analysis. Cross Cultural Management: An International Journal, 15(4), 367-378. https://doi.org/10.1108/13527600810914157

Bianchi, S. M., \& Milkie, M. A. (2010). Work and family research in the first decade of the 21 st century. Journal of Marriage and Family, 72(3), 705-725. https://doi.org/10.1111/j.1741-3737.2010.00726.x

Bianchi, S. M., Robinson, J. P., \& Milkie, M. A. (2006). Changing rhythms of American family life. New York, NY: Russell Sage Foundation.

Bittman, M., Craig, L., \& Folbre, N. (2004). Packaging care: What happens when parents utilize non-parental childcare. In M. Bittman \& N. Folbre (Eds.), Family time: The social organization of care (pp. 133-151). London: Routledge.

Bittman, M., England, P., Sayer, L., Folbre, N., \& Matheson, G. (2003). When does gender trump money? Bargaining and time in household work. American Journal of Sociology, 109(1), 186-214. https://doi.org/10.1086/378341

Bryman, A., \& Bell, E. (2007). Business research methods (2nd ed.). New York, NY: Oxford University Press.

Campbell, A. (2000). Cultural identity as a social construct. Intercultural Education, 11(1), 31-39. http://dx.doi.org/10.1080/14675980050005370

Carrim, N. M. H. (2012). 'Who am I?’ South African Indian women managers' struggle for identity: Escaping 
the ubiquitous cage (Unpublished doctoral dissertation). University of Pretoria, Pretoria, South Africa.

Carrim, N. M. H. (2016). Stepping out of the fish tank: Ethnic identity work of Indian parents. Journal of Family Issues, 37(16), 2368-2392. https://doi.org/10.1177/0192513X14561521

Carrim, N. M. H., \& Nkomo, S. (2016). Wedding intersectionality theory and identity work in organizations: South African Indian women negotiating managerial identity. Gender, Work and Organization, 23(3), 261-277. https://doi.org/10.1111/gwao.12121

Coltrane, S. (2000). Research on household labor: Modeling and measuring the social embeddedness of routine family work. Journal of Marriage and Family, 62(4), 1208-1233. https://doi.org/10.1111/j.1741-3737.2000.01208.x

Cooke, L. P. (2007). Persistent policy effects on the division of domestic tasks in reunified Germany. Journal of Marriage and Family, 69(4), 930-950. https://doi.org/10.1111/j.1741-3737.2007.00422.x

Correll, S. J., Benard, S., \& Paik, I. (2007). Getting a job: Is there a motherhood penalty? American Journal of Sociology, 112(5), 1297-1339. https://doi.org/10.1086/511799

Craig, L. (2007). How employed mothers in Australia find time for both market work and childcare. Journal of Family and Economic Issues, 28(1), 69-87. https://doi.org/10.1007/s10834-006-9047-2

Currie, J., \& Eveline, J. (2011). E-technology and work/life balance for academics with young children. Higher Education, 62(4), 533-550. https://doi.org/10.1007/s10734-010-9404-9

Das, A. (2006). Asian Indian immigrant women in the San Francisco-Oakland Bay area: Work, home, and the construction of the self (Unpublished PhD dissertation). University of California, San Diego, USA.

Department of Labour. (2016). 17th CEE Annual Report, 2016-2017. Retrieved from http://www.labour.gov.za

Erikson, E. H. (1968). Identity, youth and crisis. New York, NY: Norton.

Ezzedeen, S.R., \& Ritchey, K.G. (2008). The man behind the woman: A qualitative study of the spousal support received and valued by executive women. Journal of Family Issues, 29(9), 1107-1135. http://dx.doi.org/10.1177/0192513X08315363

Grossman, J. M., \& Charmaraman, L. (2009). Race, context and privilege: White adolescents' explanations of racial-ethnic centrality. Journal of Youth Adolescents, 38(2), 139-152. https://doi.org/10.1007/s10964-008-9330-7

Guba, E. G., \& Lincoln, Y. S. (1989). Fourth generation evaluation. Newbury Park, CA: Sage.

Gupta, S. (2007). Autonomy, dependence, or display? The relationship between married women's earnings and housework. Journal of Marriage and Family, 69(2), 399-417. https://doi.org/10.1111/j.1741-3737.2007.00373.x

Hall, S. (1990). Cultural identity and diaspora. In J. Rutherford (Ed.), Identity: Community, culture and difference (pp. 224-237). London, UK: Lawrence and Wishart.

Kan, M. Y., Sullivan, O., \& Gershuny, J. (2011). Gender convergence in domestic work: Discerning the effects of interactional and institutional barriers from large-scale data. Sociology, 45(2), 234-251. https://doi.org/10.1177/0038038510394014

Kulik, L., \& Rayyan, F. (2006). Relationships between dual-earner spouses, strategies for coping with home-work demands and emotional well-being: Jewish and Arab-Muslim women in Israel. Community, Work and Family, 9(4), 457-477. http://dx.doi.org/10.1080/13668800600925100

Luke, N., Xu, H., \& Thampi, B. V. (2014). Husbands' participation in housework and child care in India. Journal of Marriage and Family, 76(3), 620-637. https://doi.org/10.1111/jomf.12108

Matta, D., \& Knudson-Martin, C. (2006). Father responsivity: Couple processes and the coconstruction of fatherhood. Family Process, 45(1), 19-37. https://doi.org/10.1111/j.1545-5300.2006.00078.x

Narayan, A., \& Bhardwaj, G. (2005). Dual career nuclear families in India: Attitudes and social support. Indian Journal of Industrial Relations, 41(1), 79-93. http://dx.doi.org/10.4102/sajip.v42i1.1354

Quek, K. M. T., Knudson-Martin, C., Orpen, S., \& Victor, J. (2011). Gender equality during the transition to parenthood: A longitudinal study of dual-career couples in Singapore. Journal of Social and Personal Relationships, 28(7), 943-962. https://doi.org/10.1177/0265407510397989 
Rajadhyaksha, U., \& Velgach, S. (2009). Gender, gender-role ideology and work-family conflict in India. Paper presented at the Academy of Management Annual Meeting, University of Chicago, Chicago, 5-9 August. Retrieved from http://www.workfamilyconflict.ca/cms/documents/38/GRI_paper-AOM2009.pdf

Ruppanner, L. E. (2010). Cross-national reports of housework: An investigation of the gender empowerment measure. Social Science Research, 39, 963-975. https://doi:10.1016/j.ssresearch.2010.04.002

Salway, S., Jesmin, S., \& Rahman, S. (2005). Women's employment in urban Bangladesh: A challenge to gender identity? Development and Change, 36(2), 317-349. https://doi.org/10.1111/j.0012-155X.2005.00413.x

Saraff, A., \& Srivastava, H. C. (2010). Pattern and determinants of paternal involvement in childcare: An empirical investigation in a metropolis of India. Population Research and Policy Review, 29(2), 249-273. https://doi.org/10.1007/s11113-009-9139-4

Schneider, D. (2011). Market earnings and household work: New tests of gender performance theory. Journal of Marriage and Family, 73(4), 845-860. https://doi.org/10.1111/j.1741-3737.2011.00851.x

Sullivan, O. (2011). An end to gender display through the performance of housework? A review and reassessment of the quantitative literature using insights from the qualitative literature. Journal of Family Theory and Review, 3(1), 1-13. https://doi.org/10.1111/j.1756-2589.2010.00074.x

Sveningsson, S., \& Alvesson, M. (2003). Managing managerial identities: Organizational fragmentation, discourse and identity struggle. Human Relations, 56(10), 1163-1193. http://dx.doi.org/10.1177/00187267035610001

Tajfel, H., \& Turner, J. C. (1985). The social identity theory of intergroup behavior. In S. Worchel \& W. G. Austin (Eds.), Psychology of intergroup relations (2nd ed.), (pp. 7-24). Chicago, Il: Nelson-Hall.

Thébaud, S. (2010). Masculinity, bargaining, and breadwinning: Understanding men's housework in the cultural context of paid work. Gender and Society, 24(3), 330-354. https://doi.org/10.1177/0891243210369105

Valk, R., \& Srinivasan, V. (2011). Work-family balance of Indian women software professionals: A qualitative study. IIMB Management Review, 23(1), 39-50. https://doi.org/10.1016/j.iimb.2010.10.010

Vangarajaloo, M. (2011). Factors influencing the willingness of South African Indian parents to consent to their daughters pursuing tertiary education and careers (Unpublished master's thesis). University of Pretoria, Pretoria, South Africa.

Zimmerman, T. S. (2003). Intimate partnership: Foundation to the successful balance of family and work. American Journal of Family Therapy, 31(2), 107-124. http://dx.doi.org/10.1080/01926180301126

\section{Copyrights}

Copyright for this article is retained by the author(s), with first publication rights granted to the journal.

This is an open-access article distributed under the terms and conditions of the Creative Commons Attribution license (http://creativecommons.org/licenses/by/4.0/). 